\title{
NOTE ON A CASE OF CHLOROMA IN A PIG.
}

By J. Robertson, M.D., M.O.H., Birmingham.

THE fact that chloroma in a definitely recognisable form is an extremely rare disease in the human subject, and that I have not been able to ascertain the existence of any records of the disease in the lower animals, induces me to put the following well-marked case on record.

I was called to inspect the carcase and nearly all the offal of a pig which had been killed about an hour previously. The split carcase presented a remarkable appearance, resulting from patches of a bright

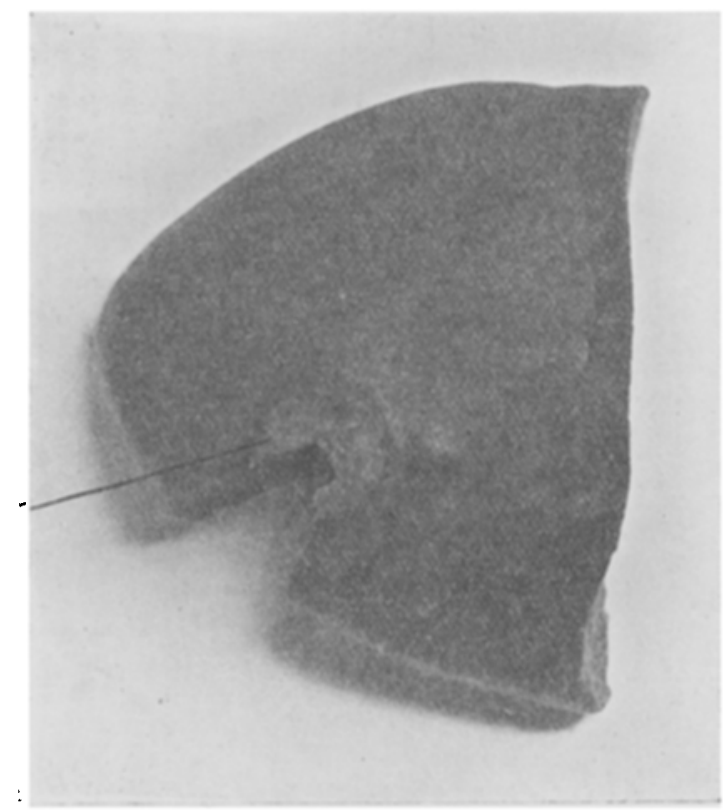

Fig. 1.

Piece of kidney showing one of the that tumours (marked by the black line) on its surface.

pea-green colour. These patches of colour were irregularly distributed over the split vertebræ, the colour being in the marrow of the spongy parts of the vertebræ. Similar patches were evident below the periosteal covering of the ribs and on other bones, also in the connective tissue in the abdomen and thorax as small masses from I to $2.5 \mathrm{~cm}$. in diameter and about $\mathrm{I} \mathrm{cm}$. thick. The colour where the tumours were near the surface was of a bright light peagreen.

One of the tumours on the surface of a piece of the kidney (capsule removed) is shown in fig. I. A photograph of a section of this tumour is shown in fig. 2. As will be seen, the tumour is intimately attached to the connective tissue of the kidney, and in structure is a typical lymphoma. 
A complete examination of the blood could not be made, as only some blood clots could be obtained. The clots showed what appeared to be an enormous increase of leucocytes, and, although no differential count could be undertaken, it was evident that the number of lymphocytes was in enormous excess.

Except for the presence of the green-coloured deposits, the organs of the pig appeared to be normal. The animal was distinctly wellnourished, and about two years of age. There was no obvious exophthalmos after death.

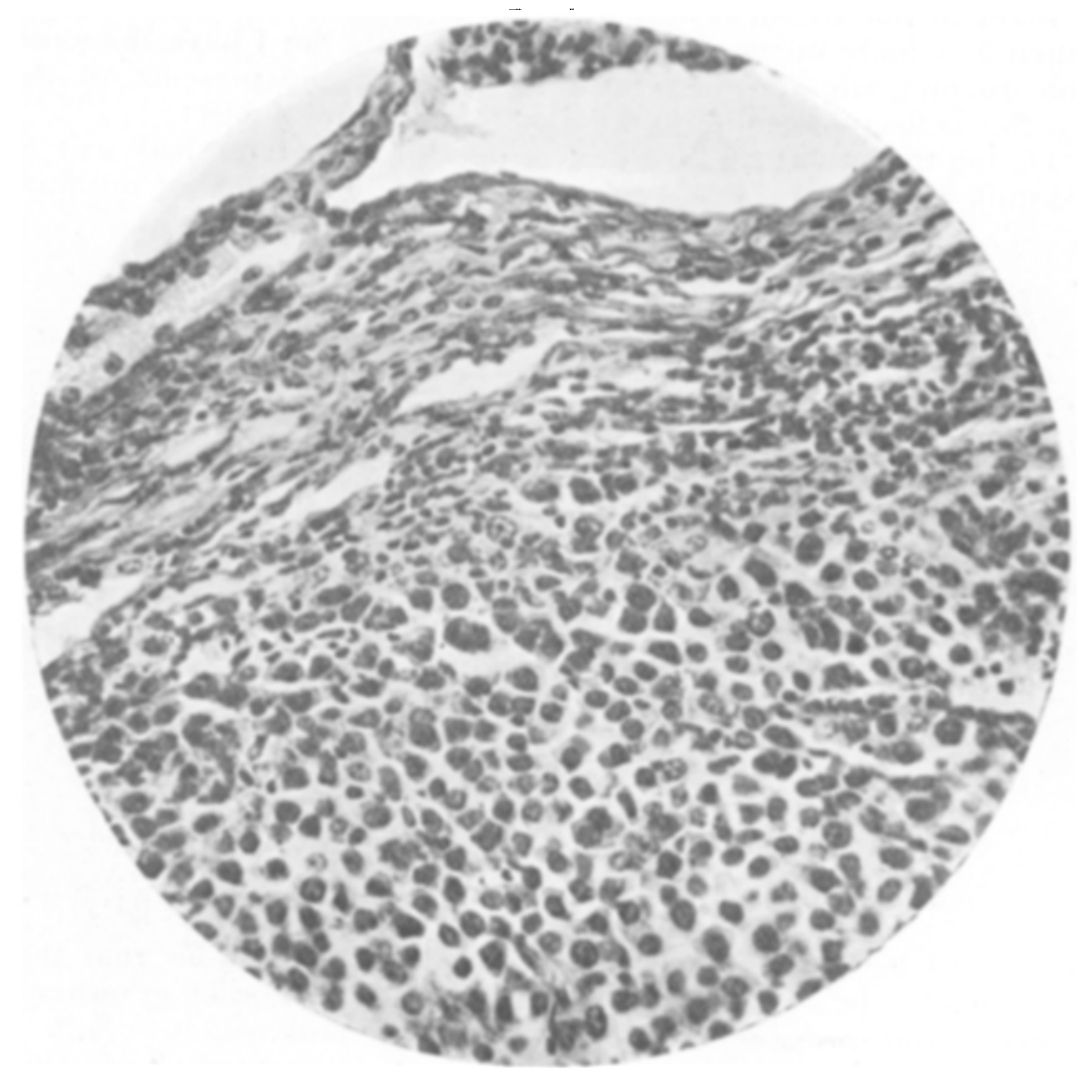

FIG. 2.

Section through chloromatous tumour showing (1) part of surface of kidncy infiltrated with new growth, and (2) the tumour structure.

It is held by medical writers on the subject that the disease usually commences in the bones of the face, and that the tumours subsequently invade the cavities of the skull, marrow of bones, and internal organs. This point was not investigated in the present case. Huber has pointed out the intimate relationship which exists between this affection and leukemia. He demonstrated that the structure of all the tumours was of a pure lymphomatous character, so that most subsequent writers have classified the tumours as lympho-sarcomas. 